BOGDAN KOSZEL

Poznań

\title{
„Uprzywilejowane partnerstwo”. Rząd Angeli Merkel (CDU/CSU-SPD) wobec integracji Turcji z Unią Europejską
}

Zabiegi Turcji o członkostwo we Wspólnotach Europejskich posiadają odległą metrykę. Już 31 lipca 1959 r. Ankara życzliwie wspierana przez rząd Konrada Adenauera złożyła wniosek o przyjęcie do EWG i 12 września 1963 r. podpisany został układ stowarzyszeniowy. Turcja uznana została przez ówczesnego ministra spraw zagranicznych RFN Gerharda Schrödera za państwo rokujące w przyszłości nadzieje na pełne członkostwo po dostosowaniu się do standardów ekonomicznych WE. Znamienna była wypowiedź pierwszego przewodniczącego Komisji EWG Waltera Hallsteina wyrażona podczas ceremonii podpisywania układu stowarzyszeniowego w Ankarze, że „Turcja należy do Europy [...] Turcja powinna być pełnoprawnym członkiem Wspólnoty"”.

Umowa stowarzyszeniowa weszła w życie 1 grudnia 1964 r. Zakończenie fazy przygotowawczej nastąiło 23 listopada 1970 r., kiedy podpisano protokół dodatkowy do umowy stowarzyszeniowej. Obowiązywał on od 1 stycznia 1973 r. i określał, że unia celna realizowana będzie w czasie fazy przejściowej w okresie od 12 do 22 lat, który miał zbliżyć Turcję jeszcze bardziej do struktur wspólnotowych. Zakładano, że w końcu tego okresu możliwy będzie swobodny przepływ towarów rolnych pomiędzy EWG i Turcją ${ }^{2}$.

Ku rozczarowaniu niemieckich elit politycznych proces dostosowywawczy Turcji przebiegał wolno, a państwo to regularnie wstrząsane było kryzysami. Nasilały się napięcia ekonomiczne i nierówności społeczne, nadużywano kary śmierci, terroryzm i zabójstwa polityczne stały się chlebem powszednim. Z powodu Cypru napięte były stosunki z Grecją, która w 1981 r. uzyskała status członka EWG, nierozwiązany pozostawał problem kurdyjski. W okresie recesji gospodarczej na Zachodzie w drugiej połowie lat siedemdziesiątych Niemcy zdecydowali się ograniczyć napływ tureckich pracowników. Po wprowadzeniu wiz dla Turków w 1980 r. za pomocą środków finansowych zachęcali ich do powrotu i zakładania własnych przedsiębiorstw i świadczenia usług.

14 kwietnia 1987 r. turecki minister ds. europejskich Ali Bozer w imieniu rządu złożył formalny wniosek o członkostwo Turcji w EWG i równocześnie w Unii Zachodnioeuropejskiej. Komisja WE obiecała w ciągu dwóch lat rozpatrzyć aplikację turecką.

Stanowisko rządu zachodnioniemieckiego wobec tej inicjatywy było niezwykle wstrzemięźliwe. Nieoficjalnie wyrażano zdziwienie, że pomimo wielu sygnałów wy-

1 W. Loth, Walter Hallstein - der vergessene Europäer, Bonn 1995, s. 126.

2 C.-T. Weick, Deutsch-türkische Erbfreundschaft, http://akademische-blaetter.de/ausgabe-3-2005/deutsch-turkische-erbfreundschaft.html. 
syłanych z Bonn i innych stolic Wspólnoty, w Ankarze zdecydowano się na tak radykalny krok, nie mający szans na powodzenie. W specjalnym oświadczeniu gabinetu powoływano się na historyczne więzi i przyjaźń łączącą Turcję z Niemcami, ale nie odrzucono wprost tureckiej prośby. Niemcy uważali, że możliwości, które dawał układ stowarzyszeniowy - w którego podpisanie RFN silnie się zaangażowała - nie zostały wyczerpane, należy go jeszcze „wypełnić treścią”. Oficjalnie zaoferowali podpisanie z EWG unii celnej ${ }^{3}$.

Wniosek o członkostwo w tej sytuacji w połowie $1989 \mathrm{r}$. został odrzucony, ale zgodnie z postulatem RFN, Komisja WE 18 grudnia 1989 r. i Rada Ministrów 5 lutego 1990 r. zobowiązały się do przedstawienia Turcji nowych propozycji zacieśnienia współpracy gospodarczej na podstawie układu stowarzyszeniowego. Jako uzasadnienie podano, że Wspólnota w okresie doniosłych przemian, które mają miejsce w Europie nie powinna wchodzić w żadne negocjacje w sprawie członkostwa na tym etapie. W efekcie dopiero w grudniu 1995 r. Parlament Europejski przyjął koncepcję unii celnej z Turcją i 1 stycznia 1996 r. weszła ona w życie ${ }^{4}$.

Z punktu widzenia rządzącej koalicji w RFN w latach 1982-1998 koalicji CDU/CSU-FDP perspektywa przyjęcia Turcji do Unii Europejskiej nigdy nie była określana jako niezbędna i celowa. Jeżeli w kołach politycznych nad Renem w końcu lat osiemdziesiątych i na początku dziewięćdziesiątych mówiło się i nawet składało niewiążące obietnice poparcia, to z góry zakładano, że niewiele to będzie kosztować, gdyż stopień integracji gospodarczo-politycznej Turcji ze strukturami Wspólnot znajdował się dopiero na wstępnym etapie.

Dla rządu kanclerza Helmuta Kohla priorytetem było EU-Osterweiterung, za czym przemawiały argumenty historyczne, emocjonalne, polityczne, gospodarcze i społeczne. Występując w roli adwokata interesów polskich, czeskich czy węgierskich w Brukseli i jednocześnie silnie angażując się na rzecz pogłębiania współpracy starych państw członkowskich $w$ ramach trzech filarów UE, Niemcy nie chciały i nie były w stanie wziąć na siebie roli promotora Turcji w Unii Europejskiej ${ }^{5}$. Uważały, że układ stowarzyszeniowy spełnia swoje zadanie, a unia celna na wiele lat powinna kształtować wzajemne relacje na linii Ankara-Bruksela. Za zaangażowaniem się na rzecz Turcji przemawiały bliskie relacje bilateralne, mniejszość turecka w RFN i strategiczne znaczenie Turcji jako wysuniętego na wschód bastionu NATO. Argumentów na „nie” było zdecydowanie więcej: słaba kondycja gospodarki tureckiej, konflikty z Grecją, problem cypryjski, kurdyjski, niedemokratyczny system sprawowania rządów, zacofanie cywilizacyjne i obcość kulturowa świata islamskiego.

3 Archiv der Gegenwart, (cyt. dalej: AdG), 1987, s. 30974.

4 A. Ambroziak, E. Synowiec, Nowe wyzwania dla Turcji $i$ UE $w$ ramach unii celnej (II), „Wspólnoty Europejskie” 1996, nr 2, s. 8; G. Schiller, The customs union EU - Turkey: a first assessment, w: W. Gumpel (ed.), Turkey as a political and economic factor in Europe and Central Asia, München 1999; S. A. Bahadir, Die Zollunion der Türkei mit der Europäischen Union: Ein Schritt auf dem Weg zur Vollmitgliedschaft?, „Aus Politik und Zeitgeschichte” 1997, B11-12, s. 33-40.

5 B. Koszel, Mitteleuropa rediviva? Europa Środkowo- $i$ Poludniowo-Wschodnia $w$ polityce zjednoczonych Niemiec, Poznań 1999; tenże, Francja i Niemcy w procesie integracji Polski ze Wspólnotami Europejskimi/Uniq Europejskq, Poznań 2003. 
Z drugiej strony w Niemczech istniała świadomość, że zamykanie przed Turcją możliwości integracji z Unią Europejską może mieć dalekosiężne konsekwencje dla zahamowania procesu demokratyzacji tego państwa, wzrostu wpływów fundamentalistów islamskich i zbliżenia się tej republiki do Iranu czy innych antyzachodnich krajów arabskich. Z tego też powodu polityka niemiecka była ostrożna, defensywna. Zachęcano Turków do demokratycznych zmian, ale też nie obiecywano zbyt wiele. Minister spraw zagranicznych Klaus Kinkel z jednej strony przekonywał Grecję, by nie blokowała Turcji drogi do Unii Europejskiej i miał duży udział w doprowadzeniu unii celnej do pomyślnego finału, a drugiej strony - mając na myśli deficyt demokracji w tym kraju - mówił o „kamieniach na drodze Turcji do UE, które trzeba będzie długo usuwać”.

W odróżnieniu do okresu sprzed 1996 r., kiedy trudno było o jednoznaczną interpretację stanowiska niemieckiego w kwestii akcesji tureckiej, w następnych latach sceptycyzm rządzącej koalicji CDU/CSU-FDP stawał się coraz bardziej widoczny. Jak się wydaje kanclerz Kohl korzyści z partnerstwa z Republiką Turecką oceniał przez pryzmat bezpieczeństwa świata zachodniego. Gdy zagrożenie komunistyczne rozwiało się z chwilą upadku ZSRR, rola Turcji jako strategicznego partnera, szachującego od południa radzieckie imperium, zdecydowanie się zmniejszyła. Podczas 16-letniego sprawowania funkcji kanclerza, Kohl tylko dwukrotnie odwiedził Turcję, w 1985 i $1993 \mathrm{r}^{7}$

Rząd CSU/CDU-FDP przed spotkaniem Rady Europejskiej w Luksemburgu w grudniu 1997 r., które miało przesądzić o rozpoczęciu rokowań akcesyjnych z pierwszą grupą państw zaczął postulować odrębne, uprzywilejowane traktowanie Turcji. 11 grudnia 1997 r. w przeddzień posiedzenia Rady Bundestag zdecydowaną większością głosów sprzeciwił się przyjmowaniu Turcji do Unii Europejskiej w najbliższym czasie. Pomimo sprzeciwu Partii Demokratycznego Socjalizmu (PDS) i wstrzymaniu się od głosu Zielonych, rządząca koalicja i SPD przyjęły rezolucję zalecającą rozpoczęcie rokowań akcesyjnych z 6 krajami z Europy Środkowo-Wschodniej i Południowej. Do Turcji skierowano propozycję „dialogu i kooperacji”, ale uzależniano to od wypełnienia kryteriów z Kopenhagi, polepszenia stosunków z Grecją i uregulowania problemu cypryjskiego ${ }^{8}$.

Po wyborach parlamentarnych w RFN we wrześniu 1998 r. w kwestii akcesji tureckiej nowy rząd koalicji SPD-Bündnis 90/Die Grünen dokonał znacznej korekty kursu forsowanego dotąd przez byłą koalicję chadecko-liberalną. Lewicowa orientacja partii rządzących uwypuklająca laicki charakter Unii Europejskiej, powołująca się na spuściznę oświecenia nie traktowała islamu jako przeszkody w integrowaniu Europy. Nie ukrywała jednak, że główną barierą stojącą na drodze tureckiej akcesji jest deficyt demokracji, brak ochrony mniejszości i nieprzestrzeganie praw człowieka. Ulegając prośbom i naciskom Turcji deklarowała poparcie dla silniejszego instytucjonalnego związania UE z tym krajem. Minister spraw zagranicznych Joschka Fischer wielokrotnie powtarzał, że Unia Europejska nie jest „wspólnotą religijną”, a kanclerz Schröder

6 M. Niklas, Zwischen Realpolitik und Idealpolitik, Hamburg 1997, s. 17.

7 AdG, 1993, s. 37941. Por. K. Ramoglu, Die politischen und wirtschaftlichen Aspekte der Beziehungen zwischen der EG und der Türkei seit den 60er Jahren bis 1992, Bonn 1994.

AdG, 1997, s. 42505-06. 
obiecał osobiste zaangażowanie w proces przyspieszenia rokowań z Turcją. Podczas spotkania Rady Europejskiej w Kolonii 3-4 czerwca 1999 r. Niemcy zakomunikowali, że podejmą starania, aby uznać Turcję za oficjalnego kandydata do członkostwa.

Po ukazaniu się 13 października drugiego raportu Komisji Europejskiej pozytywnie oceniającego postępy Turcji w zakresie dostosowywania się do norm i standardów unijnych, Rada Europejska obradująca w dniach 10-11 grudnia 1999 r. w Helsinkach wyraziła zgodę na rozpoczęcie procesu akcesyjnego. Uznała, że Turcja jest „krajem kandydującym", który powinien przystąpić do Unii na podstawie kryteriów kopenhaskich z 1993 r. Miała ona korzystać ze strategii przedakcesyjnej, której celem jest stymulowanie i wspieranie reform. W myśl przyjętych założeń mogła ona uczestniczyć w programach i agencjach wspólnotowych oraz w spotkaniach między krajami kandydującymi a Unią. Jednocześnie z myślą o Turcji zamierzano przedstawić jej szczegółowo określone Partnerstwo dla Członkostwa'.

W początkach XXI wieku sytuacja w Turcji powoli się stabilizowała i 20 czerwca 2003 roku rząd Turcji przyjął pakiet reform demokratycznych (w tym gwarancje przestrzegania praw człowieka, a przede wszystkim gwarancje praw mniejszości kurdyjskiej), dając tym samym wyraźny znak Komisji Europejskiej, iż Turcja jest w stanie dokonać gruntownych zmian w polityce i gospodarce, byle tylko rozpocząć negocjacje o członkostwo w Unii ${ }^{10}$. Perspektywa wejścia do Unii wymusiła lawinę zmian prawnych. Parlament w Ankarze zmienił ponad jedną piątą wszystkich artykułów konstytucji. Zniesiono karę śmierci, nakazano ponowne procesy w przypadkach, gdy z wyrokiem nie zgadzał się Europejski Trybunał Praw Człowieka, wprowadzono przepisy dotyczące swobody wypowiedzi, prawa do zgromadzeń, równości kobiet i mężczyzn, jak również chroniące tajemnicę dziennikarską ${ }^{11}$.

Posiedzenie Rady Europejskiej w Brukseli (16-17 grudnia 2004) w dużym stopniu podzieliło opinie Komisji i Parlamentu Europejskiego, że Turcja kontynuować będzie proces reform wewnętrznych. W celu zapewnienia nieodwracalności procesu reform politycznych oraz jego pełnego, skutecznego i kompleksowego wprowadzenia w życie, w szczególności w zakresie podstawowych wolności oraz pełnego poszanowania praw człowieka, proces ten miałby być nadal ściśle monitorowany przez Komisję Europejską. Pochwalono Turcję za podpisanie protokołu dotyczącego dostosowania Układu z Ankary w związku z przystąpieniem dziesięciu nowych Państw Członkowskich przed faktycznym rozpoczęciem negocjacji akcesyjnych ${ }^{12}$. Ustalono, że rokowania rozpoczną się 3 października 2005 r. i w Turcji decyzja ta została odebrana jako sukces i jeden z przełomowych okresów w historii kraju. Ankara zgodziła się również po długich rozmowach przyjąć najtrudniejszy dla siebie warunek, na który mocno naciskała Grecja, a mianowicie na pośrednie uznanie Cypru. Kompromis Turcja-UE

9 Posiedzenie Rady Europejskiej w Helsinkach 10-11 grudnia 1999, http://www1.ukie.gov.pl /WWW/ dok.nsf/(\$PrintView)/6D62D87A8E252469C1256E9A0033D5E8?Open; R. Rahmann, Chancen und Probleme einer Vollmitgliedschaft der Türkei in der Europäischen Union, Marburg 2003, s. 13.

${ }^{10}$ MAK, Bilet do Unii, „Gazeta Wyborcza” z 21-22 VI 2003.

11 R. Soltyk, Turcja na drodze do UE, ibidem z 24 IX 2004.

12 Konkluzje Prezydencji z posiedzenia Rady Europejskiej w Brukseli (16-17 grudnia 2004 r.), http://www.consilium.europa.eu/ueDocs/newsWord/PL/ec/83216.doc. 
osiagnięto po twardych negocjacjach, w których strona unijna obstawała przy tym, aby Turcja przed rozpoczęciem negocjacji członkowskich unormowała swoje stosunki z Cyprem. Generalnie przewidywano, że rokowania potrwają 10 lat i będą mogły być zerwane przez każdy kraj unijny, jeśli Turcja nie spełni unijnych wymagań, zwłaszcza w zakresie przestrzegania praw człowieka i swobód demokratycznych. W gospodarce zastrzeżono liczne okresy przejściowe i klauzule ochronne. O otwarciu rynku pracy dla obywateli tureckich każdy kraj unijny decydować miał samodzielnie ${ }^{13}$.

3 października 2005 roku Unia Europejska podjęła decyzję o rozpoczęciu oficjalnych negocjacji członkowskich. Przeszkodą w tej sprawie były przede wszystkim obawy przed przyjęciem muzułmańskiego kraju i tym samym rozprzestrzenienia się w UE religii islamu. Utrudnieniem było także zaangażowanie Turcji w kwestię cypryjską, zatargi polityczne z Grecją oraz nieprzestrzeganie podstawowych praw i wolności. Do ostatniej chwili nie było jednak pewne, czy decyzja ta zostanie podjęta i czy negocjacje z Turcją rozpoczną się w terminie wyznaczonym przez przywódców UE. Austria nie zgadzała się na formułę, przyjętą w grudniu 2004 roku, zgodnie z którą wspólnym celem Unii i Turcji jest członkostwo Ankary we Wspólnocie. Konsekwentnie domagała się, aby w stanowisku Unii jasno zapisano ,alternatywny” lub „przejściowy” scenariusz w sprawie akcesji Turcji $^{14}$. Wpisanie do scenariusza rokowań formuły o uzależnieniu poszerzenia Unii od jej „zdolności” absorpcyjnych nie wróżyło dobrze przyszłym negocjacjom w obliczu zbliżającej się prezydencji austriackiej w Unii, zmianach w Niemczech i perspektywy przejęcia władzy we Francji przez siły sprzeciwiające się europejskim aspiracjom Ankary.

Polityka silnego wspierania aspiracji Turcji do członkostwa w Unii odeszła jesienią 2005 r. wraz z kanclerzem Schröderem i jego dobrymi osobistymi stosunkami z premierem Recepem Tayyipem Erdoganem. Już od czasu uznania Turcji za kandydata do członkostwa w Unii Europejskiej w grudniu 1999 r., stopniowo narastała niechęć niemieckich chadeków do integrowania tego państwa ze strukturami wspólnotowymi. Jej hasłem wywoławczym było przekonanie o olbrzymiej różnicy pomiędzy „klubem chrześcijańskim" i światem wartości wyznawanym przez islam. Zamachy terrorystyczne islamskich radykałów również na terenie Turcji miały przemawiać przeciwko jej członkostwu w Unii. W opinii wiceprzewodniczacego klubu parlamentarnego CDU/CSU w Bundestagu Wolfganga Bosbacha szybkie przyjęcie Turcji do Unii oznaczałoby zaimportowanie terroryzmu do Wspólnoty. Szefowa CDU A. Merkel uważała, że istnieją inne możliwości współpracy z Turcją bez formalnego członkostwa. Wspierał ją np. bawarski minister spraw wewnętrznych Günter Beckstein, który dodawał, że wprawdzie nie należy „odpychać” Turcji, ale jej szybkie członkostwo w Unii Europej-

13 Konkluzje prezydencji z posiedzenia Rady Europejskiej w Brukseli (16-17 grudnia 2004 r.), http://www.consilium.europa.eu/ueDocs/newsWord/PL/ec/83216.doc; Unia Europejska i Turcja uzgodnity start negocjacji, „Gazeta Wyborcza” z 17 XII 2005; S. Konopacki, Droga Turcji do Unii Europejskiej, „Studia Europejskie - Centrum Europejskie Uniwersytetu Warszawskiego”, nr 1, Warszawa 2005, s. 49.

14 J. Bielecki, Los Turcji w rękach pięknej Austriaczki, „Rzeczpospolita” z 3 X 2005; tenże, Turcja w europejskiej grze, ibidem z 4 X 2005; B. Kalnoky, EU-Kommission erhöht Druck auf Ankara, „Die Welt” z 7 X 2005; Sprawozdanie ogólne Komisji Europejskiej z działalności Unii Europejskiej w 2005 roku opublikowane na mocy artykulu 212 Traktatu powolujqcego Wspólnotę Europejska, Bruksela 2005. 
skiej w obecnej sytuacji ze względu na napiętą sytuację w regionie kaukaskim i bliskowschodnim „nie leży w naszym interesie"15.

W miarę konkretyzowania się scenariusza przyjęcia Turcji do Unii Europejskiej, debata publiczna w Niemczech nabierała ostrości. Polaryzowało się stanowisko partii politycznych. Niewzruszenie za przyjęciem opowiadały się rządzące SPD i partia Zielonych oraz opozycyjna Partia Demokratycznego Socjalizmu (PDS). Przeciwne były partie chadecji, które próbowały przeciągać dyskusję sine die, wahała się FDP, która dopuszczała możliwość akcesji Ankary, ale w bliżej nieokreślonej przyszłości. Zdecydowany sprzeciw wobec europejskich aspiracji Turcji wyrażały konsekwentnie partie skrajnej prawicy - NPD i Republikanie ${ }^{16}$.

Już w styczniu 2004 r. na światowym szczycie gospodarczym w Davos A. Merkel zaskoczyła zebranych twarda, negatywną postawą wobec tureckich aspiracji do członkostwa w Unii. Uznała, że nie widzi możliwości wypełnienia przez to państwo kryteriów kopenhaskich. Uważała, że premierowi Erdoganowi nie należy ufać, gdyż jego reformy są pozorowane, a on sam zamierza wykorzystać duchowo-moralną słabość Zachodu do podminowania Unii Europejskiej ${ }^{17}$.

W miesiąc później w towarzystwie Wolfganga Schaüble kanclerz Merkel udała się do Turcji, by odwieść tureckiego premiera od forsowania formalnego rozpoczęcia negocjacji akcesyjnych i wskazać na pozytywne strony „,uprzywilejowanego partnerstwa”. Spotkała się ze stanowczą odmową. Premier Erdogan wskazał, ze naród turecki z olbrzymią determinacją wdrażający proces reform nie rozumie postawy niektórych państw członkowskich, które odmawiają Turcji wejścia do UE po tak długim stażu stowarzyszeniowym ${ }^{18}$.

W końcu sierpnia 2004 r. przywódczyni niemieckiej CDU wystosowała list do czołowych przywódców partii konserwatywnych z Europejskiej Partii Ludowej z propozycją ustanowienia z Turcją ,uprzywilejowanego partnerstwa” zamiast pełnego członkostwa tego kraju w UE. Miała świadomość, że wśród konserwatystów starej „15" reprezentowanych w Parlamencie Europejskim istniały głębokie podziały. Eurodeputowani z Hiszpanii, Grecji, Portugalii, Włoch, krajów Beneluksu, Wielkiej Brytanii i państw skandynawskich skłaniali się do rozpoczęcia rozmów akcesyjnych, swój sprzeciw wyrażali posłowie z Niemiec, Austrii i częściowo z Francji ${ }^{19}$. W Niemczech noszono się z zamiarem rozpoczęcia akcji zbierania podpisów przeciwko tureckiemu wejściu do Unii Europejskiej. Obok A. Merkel gorącymi zwolennikami takiego rozwiązania byli prominentni politycy CDU i CSU - Michael Glos i Edmund Stoiber, wątpliwości natomiast nie kryli inni politycy CDU - Volker Rühe, Ruprecht Polenz

15 Möglicher EU-Beitritt der Türkei heizt Streit an, „Die Welt” z 26 IX 2004; Anr, Spór w Niemczech o przystapienie Turcji do UE, „Gazeta Wyborcza” z 23 XI 2003. Por. P. von Ondarza, Türkei und christliches Abendland: was in der Debatte um einen Beitritt vergessen wird: die Gechichte des Christentums, „Internationale Politik” 2005, nr 7, s. 90-93.

${ }_{16}$ Zob. H. Winter, Die Türkei in der EU : Schreckensbild oder natürliche Entwicklung?, „Liberal” 2005, nr 2, s. 45-47, 20; C. Fiedler, ,, Sicherheitszugewinn für Europa”, „Die Welt” z 18 XII 2004.

17 Ch. Keese, Rückschlag für die Union, „Die Welt” z 19 X 2004.

18 Angela Merkel stößt bei Besuch auf Skepsis - Türkei lehnt „,privilegierte Partnerschaft” mit EU ab, ,Sűddeutsche Zeitung” z 17 II 2004; Türkei-Reise - Botin der Ablehnung, ibidem z 16 II 2004.

${ }_{19}$ M. Hollstein, K. Ridderbusch, Brüssels Konservative tief gespalten, „Die Welt” z 16 X 2004; Offensive Merkels gegen EU-Vollbeitritt der Türkei, „Welt am Sonntag” z 27 VIII 2004. 
i Matthias Wissmann. Przeciwnicy tureckiej akcesji powoływali się na wyniki najnowszych sondaży. Według instytutu badania opinii publicznej Emnid na zlecenie dziennika „Die Welt” we wrześniu 2004 r. za przyjęciem Turcji do Unii opowiadało się tylko $34 \%$ ankietowanych Niemców, podczas gdy jeszcze w kwietniu tego samego roku było to $39 \%$. Liczba przeciwników w tym samym czasie powiększyła się do $57 \%{ }^{20}$.

W grudniu 2004 r. A. Merkel i jej zwolennicy musieli przełknąć gorzką pigułkę, gdy na unijnym szczycie przyjęto datę rozpoczęcia formalnych negocjacji z Turcją. Ta decyzja nie oznaczała odstapienia jednak od forsowania idei ,uprzywilejowanego partnerstwa", które doczekało się ogólnikowej prezentacji. W szerokich zarysach koncepcja ta zasadzała się na tezie, że pełne członkostwo Turcji w Unii Europejskiej z wielu powodów jest obecnie niemożliwe i należy szukać rozwiązania zastępczego, ale wychodzącego naprzeciw europejskim aspiracjom Ankary. „Uprzywilejowane partnerstwo" polegać miało na wyłączeniu Turcji z grona innych państw stowarzyszonych i zapewnienia jej statusu ekskluzywnego. Konkretnie postulowano wzmocnienie współpracy instytucjonalnej, rozbudowę i budowę nowych struktur, które miałyby temu służyć. Wymieniano tutaj propozycje utworzenia Komisji i Rady UE-Turcja, czy też Komisji Parlamentarnej UE-Turcja, które monitorować miałyby funkcjonowanie „uprzywilejowanego partnerstwa”. Nie zamierzano przyjmować Turcji do Europejskiego Obszaru Gospodarczego, ale obiecano rozwój indywidualnych programów pomocowych i dopuszczano możliwość włączenia jej do czterech unijnych swobód (swobodnego przepływu kapitału, usług, towarów), przy pewnych ograniczeniach dotyczących ruchu osobowego. Propozycje niemieckich chadeków szły również w kierunku włączenia Turcji do Europejskiej Polityki Zagranicznej i Bezpieczeństwa oraz do Europejskiej Polityki Bezpieczeństwa i Obrony. Obiecano jej wzajemne konsultacje i ustalanie wspólnych stanowisk, udział w posiedzeniach ministrów spraw zagranicznych, a także uczestnictwo w tworzeniu grup bojowych. „Uprzywilejowane partnerstwo” przewidywało zacieśnienie współpracy urzędów i instytucji wymiaru sprawiedliwości i spraw wewnętrznych, zwłaszcza w zakresie zwalczania terroryzmu ${ }^{21}$.

Po przedterminowych wyborach do Bundestagu 18 września 2005 r. uformowany został rząd wielkiej koalicji CDU/CSU-SPD z A. Merkel jako kanclerzem. Konieczność sformowania rządu koalicyjnego siłą rzeczy musiała znaleźć swoje odbicie w modyfikacji stanowiska partii Unii wobec aspiracji tureckich do członkostwa. Resort spraw zagranicznych znalazł się w rękach zaufanego współpracownika byłego kanclerza Franka-Waltera Steinmeiera, co oznaczało gwarancję pewnej ciągłości w niemieckiej polityce zagranicznej. A. Merkel zależało również na odbudowie nadwerężonych przez socjaldemokratów stosunków z Waszyngtonem, który ze względów polityczno-strategicznych jednoznacznie opowiadał się za przystąpieniem Turcji do UE. Polityka twardego „nie” na szczycie w Brukseli w październiku 2005 r. poniosła też porażkę, albowiem znikąd Niemcy nie otrzymały silnego wsparcia. Takie okoliczności

20 EU-Beitritt der Türkei stößt auf immer mehr Ablehnung, „Welt am Sonntag” z 17 IX 2004; Streit um Unterschriften-Aktion gegen Türkei-Beitritt, ibidem z 13 X 2004.

${ }^{21}$ K.-Th. zu Guttenberg, Die Beziehungen zwischen der Türkei und der EU-eine ,priviligierte Partnerschaft”, „Aktuelle Analysen” 2004, nr 33, Hanns Seidel Stiftung, München 2004, s. 14-15; Türkei: Partnerschaft statt EU-Mitgliedschaft, „Welt am Sonntag” z 16 X 2004. 
spowodowały odstapienie niemieckiej chadecji od krytycznego podejścia do tureckiego członkostwa, ale też nie zwiastowały kontynuacji wcześniej polityki wspierania europejskich aspiracji Ankary. Kanclerz Merkel dobrze orientowała się, że w samej SPD opinie na temat członkostwa Turcji też były podzielone. Zaistniałe polityczne zawirowanie dobrze uwidoczniło się już w umowie koalicyjnej pomiędzy CDU/CSU-SPD z 11 listopada 2005 r., gdzie w akapicie poświęconym Turcji i jej zabiegom o członkostwo w Unii Europejskiej starannie ważono każde słowo. Stwierdzono, że Niemcy mają ,,szczególny interes” w pogłębianiu wzajemnych stosunków i powiązaniu Turcji z Unią Europejską. Przychylnie odniesiono się do rozpoczęcia negocjacji akcesyjnych, ale ich zamknięcie uznano za sprawę otwartą. Uznano, że proces akcesji stwarza dla obu stron olbrzymie wyzwanie gospodarcze, demograficzne i kulturalne. Potwierdzono wsparcie dla kontynuacji procesu demokratycznych reform. Wskazano, że mandat negocjacyjny Komisji Europejskiej uzależniony będzie nie tylko od ścisłego wypełniania kryteriów kopenhaskich, ale i zdolności Unii do poszerzenia. W końcowych zdaniach zastrzeżono, że gdyby okazało się, że Unia nie jest gotowa do przyjęcia Turcji, bądź Turcja członkostwa w Unii, to dotychczasowe wzajemne zobowiązania muszą być respektowane. I w takiej sytuacji „Turcja musi w dalszym ciagu rozwijać swoje uprzywilejowane stosunki z Unią Europejską i być z nią możliwie jak najściślej powiązaną"22.

Od początków 2006 r. zaznaczyło się wyraźnie usztywnienie Niemiec w sprawie przyspieszenia procesu integracji Turcji z Unią Europejską. W maju 2006 r. podczas debaty nad niemiecką polityką zagraniczną w Bundestagu kanclerz A. Merkel dobitnie stwierdziła, że „Europa musi mieć swoje granice. Organizm bez granic nie jest w stanie funkcjonować". Choć Merkel nie wymieniła nazwy żadnego kraju, posłowie dobrze orientowali się, że ma na myśli Turcję ${ }^{23}$.

Miesiąc wcześniej na dorocznym szczycie europejskich partii konserwatywnych, dominujących w Parlamencie Europejskim ton dyskusji nadawał kanclerz rządu austriackiego Wolfgang Schüssel, którego kraj przewodniczył Unii w pierwszej połowie 2006 r. Rzucało się w oczy, że w wypowiedziach A. Merkel zabrakło już nawet sformułowań o „uprzywilejowanym partnerstwie”. Kanclerz przekonywała, że o dalszym poszerzeniu Unii nie może być mowy bez wcześniejszego zreformowania jej instytucji, a nawet przyjęcia europejskiej konstytucji ${ }^{24}$.

12 czerwca 2006 r. ministrowie spraw zagranicznych UE na posiedzeniu w Luksemburgu pomimo pewnych zastrzeżeń w kwestiach cypryjskich wyrazili zgodę na formalne otwarcie rokowań i jednoczesne zamknięcie - z powodu braku kontrowersji - w pierwszym obszarze negocjacyjnym „Nauka i badania”. Cypr postanowił jednak wykorzystać okazję do przypomnienia o niezrealizowanych obietnicach Turcji w sprawie rozszerzenia unii celnej o nowe państwa UE. Przypomniano, że cypryjskie statki i samoloty nie są wpuszczane do tureckich portów i na tureckie lotniska. Ostatecznie po kilku godzinach

22 Gemeinsam für Deutschland - mit Mut Mut und Menschlichkeit. Koalitionsvertrag zwischen CDU, CSU und SPD , 11.11.2005, s. 129-130, http://www.cdu.de/doc/pdf/05_11_11_Koalitionsvertrag.pdf.

${ }_{23}$ Regierungserklärung: Wir brauchen den Verfassungsvertrag, „Frankfurter Allgemeine Zeitung” z 12 V 2006; B. T. Wieliński, Debata o niemieckiej polityce zagranicznej w Bundestagu, „Gazeta Wyborcza" z 12 V 2006.

24 J. Bielecki, Europa zamyka drzwi, „Rzeczpospolita” z 1 IV 2006. 
negocjacji Cypr ustapił pod warunkiem zobowiązania Turcji do otwarcia portów do końca 2006 r. Premier Erdogan zapowiedział, że tego nie zrobi, dopóki zamieszkana przez ludność turecką północna czesść Cypru nie doczeka się międzynarodowego uznania. Rozpoczęcie negocjacji nie było równoznaczne z tym, że Turcja zostanie członkiem Unii Europejskiej, ale taką perspektywę znacznie przybliżało. Francja i Austria zastrzegły, że w każdej chwili rokowania z Ankarą mogą zostać zerwane, gdyby okazało się, że nie są przestrzegane w tym kraju zasady demokracji i prawa człowieka. Zapisano także, że alternatywą dla Turcji może stać się tzw. specjalne partnerstwo z Unią ${ }^{25}$.

W pierwszej połowie $2006 \mathrm{r}$. Turcja wprowadziła liczne zmiany do prawa krajowego mające demokratyzować ustrój republiki. Zainicjowano publiczną debatę nad potrzebą zmiany systemu wyborczego, który wymagał od partii $10 \%$ poparcia na poziomie krajowym, aby uzyskać reprezentację w parlamencie. Rząd przedłożył nowy pakiet reform w czerwcu 2006 r., obejmujący wiele dziedzin związanych z politycznymi kryteriami uzyskania członkostwa z Kopenhagi. Parlament turecki przyjął ustawę o utworzeniu stanowiska Rzecznika Praw Obywatelskich. Miał on się zajmować wnioskami od osób cywilnych i prawnych w odniesieniu do działań administracyjnych i stanowił priorytet Partnerstwa Akcesyjnego. W styczniu 2006 r. przyjęto prawo dotyczące zrzeszeń władz lokalnych. Pozwalało ono wioskom, zarządom miast i administracji lokalnej na inicjowanie wspólnych projektów. Organizacje społeczeństwa obywatelskiego stały się bardziej widoczne i lepiej zorganizowane, zwłaszcza od czasu przyjęcia prawa o zrzeszeniach. Wzrastała liczba i różnorodność organizacji pozarządowych. Według prawa udoskonalającego odpowiednie wytyczne Wojskowego Prawa Karnego, przyjętego w czerwcu 2006 r., żaden cywil nie mógł być sądzony przed trybunałami wojskowymi w okresie pokoju. W marcu 2006 r. miała miejsce ratyfikacja Międzynarodowej Konwencji Praw Cywilnych i Politycznych dotycząca zniesienia kary śmierci, w czerwcu weszła w życie Konwencja Narodów Zjednoczonych przeciwko korupcji. W odpowiedzi na eskalację terroryzmu, wprowadzono poprawki do prawa antyterrorystycznego. 27 września 2006 r. Turcja ratyfikowała poprawioną Europejską Kartę Praw Społecznych. Została zaakceptowana z zastrzeżeniami dotyczącymi prawa do organizowania się i prawa do zbiorowych negocjacji ${ }^{26}$.

Rząd turecki był przekonany, że w odpowiedzi na widoczny postęp w reformowaniu kraju, Unia Europejska odpowiednio doceni jego wysiłki. Tak się jednak nie stało i w Turcji wyniki szczytu luksemburskiego przyjęto z wielkim rozczarowaniem. Niejako w sposób automatyczny odbiło się to na spowolnieniu tempa reform, co z kolei sprowokowało nowe zarzuty instytucji Unii Europejskiej. We wrześniu Parlament Europejski przedstawił listę tureckich niedociągnięć, domagając się wprowadzenia szybkich zmian. Wyrażono niezadowolenie z powodu opieszałości rządu w procesie reform, zwłaszcza w zakresie wolności słowa, praw religijnych i praw mniejszości czy relacji między

25 EU startet Verhandlung mit Türkei über Beitritt, ,Die Welt” z 12 VI 2006; A. Słojewska, Rozszerzenie z przeszkodami, „Rzeczpospolita” z 13 VI 2006. Por. M. A. Cichocki, Turcja rozpoczyna negocjacje, „Komentarze Natolińskie”, nr 2, Warszawa 2005; H. Kramer, EU-Türkei-Beitrittsverhandlungen - nur teilweise aufgeschoben?, „Südosteuropa” 2007, $\mathrm{nr} 4$, s. 461-473.

${ }^{26}$ Relacje Turcja-UE, Ambasada RP w Ankarze, http://www.ankara.polemb.net/index.php?document=18. 
urzędnikami cywilnymi i nadal bardzo wpływowym korpusem oficerskim. Zwrócono uwagę, że kodeks karny wciąż zezwala w Turcji na więzienie osób tylko z powodu wyrażanych przez nie poglądów, wskazując na przykłady wyroków w stosunku do dziennikarzy i wydawców, którzy np. pozwolili sobie pisać o rzezi Ormian w Turcji w latach 1915-1917. Eurodeputowani krytykowali też sytuację mniejszości religijnych, w tym ataki na kościoły chrześcijańskie w Turcji, oraz projekt ustawy antyterrorystycznej, który zagrażał podstawowym sferom wolności. Zażądali od Turcji jak najszybszego uregulowania stosunków z Cyprem, w tym respektowania tzw. protokołu ankarskiego, zobowiązującego Ankarę do wpuszczania do swych portów i lotnisk cypryjskich statków i samolotów. Ostrzegano, że brak pełnego wykonania tych zobowiązań do końca tego roku negatywnie wpłynie na dalsze negocjacje. Parlament Europejski stanowczo wezwał też Ankarę do uznania ludobójstwa popełnionego na ludności ormiańskiej w okresie I wojny światowej, po raz pierwszy uznając, iż spełnienie tego postulatu powinno być niezbędnym warunkiem ewentualnego członkostwa Turcji w UE ${ }^{27}$. Deputowany CDU do Parlamentu Europejskiego Elmar Brok zarzucał Turcji, że każdą krytyczną uwagę z zewnątrz przyjmuje jako atak na rządzącą Partię Sprawiedliwości i Rozwoju (AKP) i zapomina, że „kryteria polityczne powinny być spełnione na początku, a nie na końcu rokowań”. 6 listopada 2006 r. w krytycznym tonie wypowiedziała się frakcja poselska Sojuszu90/Zielonych. Wskazała na spowolnienie procesu reform i brak politycznej woli do rozwiązania problemu cypryjskiego. Jednocześnie winą za zaistniałą sytuację częściowo obarczyła CDU, której ,,populistyczne wypowiedzi wzmacniają przeciwników reform w Turcji”. Wyrażono obawy, że zbliżająca się prezydencja A. Merkel w Unii stać będzie pod znakiem forsowania koncepcji „uprzywilejowanego partnerstwa", co całkowicie może zniechęcić polityków tureckich do kroczenia drogą reform. Wypowiedziała się przeciwko zawieszeniu bądź spowolnieniu rozmów UE z Turcją w sprawie członkostwa ze względu na jej geostrategiczne położenie i pełnioną przez nią funkcję łącznika pomiędzy światem islamu i chrześcijaństwa ${ }^{28}$.

Na początku października 2006 r. z dwudniową wizytą do Stambułu i Ankary udała się kanclerz A. Merkel, pragnąc zorientować się w zaistniałej sytuacji i zmusić rząd Erdogana do ustępstw. Publicznie oświadczyła, że Niemcy nie zmienią zdania i nie wycofają się z obietnic, jakie UE złożyła Turcji w sprawie perspektyw jej członkostwa. Dała do zrozumienia, że choć partie koalicji CDU/CSU są sceptyczne w kwestii przyjęcia Turcji do UE, to jednak jako kanclerz koalicyjnego rządu, w którym uczestniczą socjaldemokraci popierający członkostwo Ankary w UE, szanuje zasadę pacta sunt servanda. Przede wszystkim kanclerz Merkel wezwała tureckie władze, by otworzyły porty dla statków z greckiej Republiki Cypru i naciskała w tym kierunku na premiera Erdogana ${ }^{29}$.

27 J. Bielecki, Eurodeputowani zaostrzaja ton w sprawie negocjacji z Turcja, „Rzeczpospolita” z 5 IX 2006.

${ }_{28}$ EU-Parlament zeigt der Türkei die gelbe Karte, „Neue Zürcher Zeitung” z 27 IX 2006; Gelbe Karte für Ankara, „Das Parlament” z 2.10.2006; Gelbe Karte für die Türkei. Beitrittsverhandlungen mit der EU nicht abbrechen, Bundestagsfraktion Bündnis 90-Die Grünen. 9. November 2006, http://www.gruene-bundestag.de/cms/europaeische_union/dok/88/88092.html.

29 P. Müller, Umdenken am Bosporus, „Die Welt” z 8 X 2006; Merkels Muskelspiele mit Erdogan, „Der Spiegel” z 05 X 2006; M. Thumann, ,, Schöne Tradition”, ,Die Zeit” z 6 X 2006; Keine Einigung in der Zypern-Frage, „Frankfurter Allgemeine Zeitung” z 5 X 2006; K.Z., Niemcy zgodzq się na Tur- 
Przed spotkaniem Rady Europejskiej w Brukseli w końcu listopada 2006 r. Komisja Europejska zasugerowała, aby Unia zamroziła rozmowy w 8 z 35 rozdziałów negocjacyjnych - wszystkich tych, które miały mniejszy lub większy związek z nieuznawaniem przez Turcję Cypru oraz z niewpuszczaniem do Turcji cypryjskich statków i samolotów. Obradujący przed szczytem ministrowie spraw zagranicznych po wielogodzinnych naradach, uwzględnili opinię Komisji, dopuszczając jednak możliwość otwierania kolejnych rozdziałów, ale bez możliwości ich zamykania ${ }^{30}$.

Na spotkaniu Trójkąta Weimarskiego w Mettlach w Zagkębiu Saary 5 grudnia 2006 r. kanclerz Merkel domagała się specjalnego raportu Komisji Europejskiej dotyczącego wypełniania przez Turcję protokołu z Ankary i kolejnego raportu na lata 2007-2009 monitorującego postępy Turcji we wdrażaniu unijnych norm i standardów. Obecny na spotkaniu prezydent Polski Lech Kaczyński potwierdził, że Polska sprzyja europejskim aspiracjom Turcji, podzielił jednak pogląd niemieckiej kanclerz i prezydenta Jacques'a Chiraca w kwestii konieczności częściowego zawieszenia negocjacji z Ankarą wobec odmowy otwarcia portów dla statków cypryjskich ${ }^{31}$.

Zgodnie z oczekiwaniami, brukselskie posiedzenie Rady Europejskiej 14-15 grudnia 2006 r. zakończyło się przyjęciem stanowiska Komisji Europejskiej i ministrów spraw zagranicznych. Jeszcze przed szczytem A. Merkel prezentując w Bundestagu punkty ciężkości zbliżającej się niemieckiej prezydencji w Unii wysłała sygnał, że o sprawie tureckiego członkostwa zadecyduje ścisłe wypełnianie przyjętych przez to państwo zobowiązań i reform. Podtrzymała to w Brukseli i zgodziła się z nią większość unijnych przywódców ${ }^{32}$.

28 marca 2007 r. po dziesięciu miesiącach od otwarcia i zamknięcia pierwszych rozdziałów, zdecydowano się uruchomić rozmowy na temat „polityki przemysłowej i przedsiębiorczości”. Kanclerz A. Merkel przewodząca Radzie Europejskiej w pierwszej połowie 2007 r., zapowiedziała, że do czerwca otwarte zostaną jeszcze trzy rozdziały (statystyka, polityka gospodarcza i monetarna oraz kontrola finansowa). W pierwszej kolejności wybrano rozdziały stosunkowo proste i niekontrowersyjne. Orientowano się, że komplikacje pojawią się wówczas, gdy na stół negocjacyjny trafią rolnictwo, polityka regionalna czy standardy demokratyczne. Były to dziedziny, w których Turcja odnotowywała znaczne opóźnienia, a w grę wchodziły poważne sumy na unijne wsparcie tych obszarów.

cję w Unii. Obietnice Angeli Merkel, ,Rzeczpospolita” z 7 X 2006; Merkel w Ankarze, „Gazeta Wyborcza" z 6 X 2006.

${ }^{30}$ K. Niklewicz, Bruksela mówi Turcji stop, „Gazeta Wyborcza” z 29 XI 2006; tenże, Jak Unia ukarze Turcję, ibidem 11 XII 2006; J. Leithäuser, Merkel in der Türkei. Fastenbrechen unter europäischem Sternenkranz, „Frankfurter Allgemeine Zeitung” z 6 X 2006.

31 Chirac i Merkel: w sporze z Rosja możecie na nas liczyć, „,Rzeczpospolita” z 6 XII 2006; Türkei-Verhandlungen Ultimatum nein, Bericht unbedingt, ,Süddeutsche Zeitung” z 6 XII 2006; Türkei-Beitritt: EU will Verhandlungen mit Ankara teilweise aussetzen, „Frankfurter Allgemeine Zeitung” z 6 XII 2006; Kaczynski, Chirac und Merkel beim Treffen des ,,Weimarer Dreiecks” in Mettlach, „Die Welt” z 5 XII 2006; por. P. Bocev, Chirac et Merkel assouplissent leur position sur la Turquie, „Le Figaro” z 6 XII 2006.

A. Słojewska, Nie ma klimatu dla dalszego poszerzenia Unii, „Rzeczpospolita” z 15 XI 2006; Ch. Schiltz, Ankara soll Hafen und Flughafen schnell offnen, „Die Welt” z 14 XII 2006; Die EU steuert auf eine Einigung zu, ibidem z 12 XII 2006. 
Przed zbliżającymi się przyspieszonymi wyborami do parlamentu tureckiego, wizytę w Niemczech w kwietniu 2007 r. złożył premier Erdogan. Jego podróż na międzynarodowe targi do Hanoweru, gdzie Turcja była gościem honorowym, poprzedziła wielotygodniowa fala krytyki pod adresem Unii Europejskiej i Niemiec w mediach i kręgach politycznych Turcji. Szczególnie cierpko przyjęto w Ankarze i Stambule fakt, że przedstawiciele Turcji nie zostali zaproszeni do Berlina na niedawne uroczystości 50-lecia podpisania traktatów rzymskich, mimo że kraj ten posiadał najdłuższy „staż stowarzyszeniowy" w Unii, a Turcy stanowili największą społeczność napływową w Niemczech. Na konferencji prasowej kanclerz A. Merkel wyraziła nadzieję na postęp w rokowaniach UE z Turcją, ale jako warunek wstępny określiła normalizację stosunków z Cyprem. Zapowiedziała, że do lipca, do końca przewodnictwa Niemiec w Unii, zostaną otwarte rokowania nad dwoma nowymi rozdziałami negocjacyjnymi ${ }^{33}$.

Wiele ożywienia do turecko-unijnych relacji wprowadziły rezultaty wyborów parlamentarnych przeprowadzone 22 lipca 2007 r. Zwyciężyło w nich ponownie ugrupowanie rządzące premiera Erdogana Partia Sprawiedliwości i Rozwoju, zdobywając blisko 47\% głosów. Dawało jej to 341 mandatów w 550-miejscowym Wielkim Zgromadzeniu Narodowym i tym samym możliwość zmiany konstytucji. Unia Europejska pozytywnie odnotowała taki wynik uważając, że wzmocni to proces niezbędnych reform przybliżający Turcję do członkostwa. Minister spraw zagranicznych Niemiec F.-W. Steinmeier uważał, że Erdogan otrzymał demokratyczny mandat i możliwość olbrzymiego wpływu na proces reform gospodarczych i społecznych, a sekretarz generalny SPD Hubertus Heil dodawał, że zwycięstwo Erdogana to poparcie społeczne dla proeuropejskiego kursu obecnego rządu. Entuzjastyczne wypowiedzi studził Eckart von Klaeden rzecznik frakcji CDU/CSU w Bundestagu ds. polityki zagranicznej, który domagał się rozwiązania problemu cypryjskiego i rzeczywistych, a nie pozorowanych reform. Jego partner z CSU i przewodniczący wydziału zagranicznego Bundestagu Karl-Theodor zu Guttenberg nadal podtrzymywał pogląd swej partii, czy w ogóle jest sens przyjmowania Turcji w poczet nowych członków Unii ${ }^{34}$.

Premier Erdogan po wyborczym sukcesie zapewniał, że jego kraj przyspieszy demokratyczne przeobrażenia, ale spore wątpliwości wywołało w miesiąc później wybranie na prezydenta kraju - wprawdzie dopiero w trzecim głosowaniu - islamisty Abdullaha Güla. Wybór ten z niechęcią zaakceptowała armia turecka mająca silny wpływ na bieg życia politycznego, nie brakowało też niechętnych głosów w samej Unii Europejskiej ${ }^{35}$. Jeszcze przed pójściem do urn w Turcji, zwycięzca wyborów prezydenckich we Francji

33 EU und Türkei: die enge Zusammenarbeit weiter intensivieren, Presse- und Informationsamt der Bundesregierung, http://www.bundesregierung.de/Content/DE/Artikel/2007/04/2007-04-15-bk-erdogan-hannover.html; Merkel do Erdogana: Wasze przystapienie do UE to odległa przyszłość, „Gazeta Wyborcza” z 16 IV 2007; H. Kramer, EU-Turkey Negotiations. Still in the „Cyprus Impresse”, „SWP-Comments” 2007, nr 1.

34 EU will eine starke Regierung Erdogan, „Die Welt” z 23 VII 2007; Turcja: rzadzaca partia zwyciężyła w wyborach, „Gazeta Wyborcza” z 23 VII 2007; Wahlsieg der AKP: EU hofft auf weitere Reformen in der Türkei, „Frankfurter Allgemeine Zeitung” z 23 VII 2007.

${ }_{35}$ H. Kramer, Türkei:Neue Kämpfe an alten Fronten, „SWP-Aktuell”, nr 33, Juli 2007. Por. Z. Baran, Türkei: Demokratie in Gefahr?: Massendemonstrationen, Wahl-Turbulenzen und eine harsche Warnung des Generalstabs beunruhigen den Westen, „Internationale Politik” 2007, nr 6, s. 129-133. 
Nicolas Sarkozy nie zgodził się, by rozpocząć negocjacje z Ankarą w ważnym obszarze polityki gospodarczej i monetarnej. Już wcześniej jako minister i kandydat na prezydenta Sarkozy zdecydowanie sprzeciwiał się członkostwu Turcji. Wpisywał się w nastroje większości Francuzów, którzy odrzucili w 2005 r. traktat konstytucyjny m.in. z powodu lęku przed dalszym rozszerzaniem UE. Zamiast przyjęcia do Unii Sarkozy proponował Turcji członkostwo w bliżej niesprecyzowanej „unii państw śródziemnomorskich”. Latem 2007 r. zażądał zwołania 10-12-osobowego „gremium mędrców”, którzy przed wyborami do Parlamentu Europejskiego w 2009 r. przygotowaliby specjalny raport o granicach ekspansji Unii i jej celach na lata 2020-2030. Od tego uzależnił cofnięcie francuskiego weta w sprawie otwarcia rozdziału o polityce monetarnej i gospodarczej ${ }^{36}$.

Podczas prezydencji portugalskiej w drugiej połowie $2007 \mathrm{r}$. kluczową sprawą było podpisanie „traktatu reformującego" UE i problemy tureckie zepchnięte zostały na plan dalszy. 13 grudnia w stolicy Portugalii doszło do podpisania traktatu lizbońskiego, który wzmacniał wewnętrznie UE i otwierał drzwi do dalszych poszerzeń. Z kolei priorytetem przewodnictwa słoweńskiego w pierwszej połowie 2008 r. były kwestie związane z integracją z Unią Europejską obszaru Bałkanów Zachodnich i przede wszystkim szukanie rozwiązania kryzysu związanego z procesem ratyfikacji traktatu lizbońskiego. W konkluzjach ze szczytu Rady Europejskiej 19-20 czerwca 2008 r. wiele miejsca poświęcono Bałkanom, Turcja natomiast ulokowana została tylko w ogólnych zapisach dotyczących wprowadzania w życie Unii dla Śródziemnomorza ${ }^{37}$. Po referendum w czerwcu w 2008 r., kiedy 53,4\% Irlandczyków wypowiedziało się przeciwko układowi z Lizbony, już w sierpniu pojawił się kryzys na Kaukazie związany z konfliktem gruzińsko-rosyjskim, który zaabsorbował polityków unijnych i niemieckich.

W 2008 r. po nieudanym referendum w Irlandii, proces reform wewnętrznych w Turcji był kontynuowany, choć nie posiadał on wyrazistego oblicza i tempa. Wiceprzewodniczący Komisji Europejskiej Günter Verheugen wprawdzie podkreślał, że Turcja „nie będzie więźniem irlandzkiego «nie»”, ale inni politycy niemieccy jak np. szef bawarskiej CSU Erwin Huber twierdził, że należy to wykorzystać i zastopować rokowania z Turcją do czasu wyjaśnienia przyszłości traktatu lizbońskiego ${ }^{38}$.

Na początku 2008 r. rząd AKP zniósł zakaz noszenia chust muzułmańskich na państwowych uniwersytetach, co spowodowało reakcję prokuratury generalnej i wniosek o rozwiązanie Partii Sprawiedliwości i Rozwoju i wykluczenie z życia publicznego premiera Erdogana, i prezydenta Abdullaha Güla. W październiku trybunał konstytucyjny uznał, że noszenie chust muzułmańskich przez studentki na terenie uniwersytetów byłoby sprzeczne z zasadą świeckości państwa. Inicjatywa ta i decyzja sądu wywołały liczne komentarze w RFN i UE. Wniosek prokuratora ostro skrytykowała Bruksela, według której zaszkodzi on staraniom Turcji o członkostwo w UE. W opinii komisarza ds. rozszerzenia UE Olli Rehna w normalnej europejskiej demokracji o polityce dyskutuje się w parlamencie, a decyzje zapadają w lokalach wyborczych, a nie na

36 P. Szczerkowski, Francja wypycha Turcję z Unii, „Gazeta Wyborcza” z 26 VI 2007; Frankreich: Sarkozy: Weisenrat soll Europas Mission klären, „Frankfurter Allgemeine Zeitung” z 9 IX 2007.

37 Rada Europejska w Brukseli 19-20 czerwca 2008 r. Konkluzje prezydencji, http://www.consilium.europa.eu/ueDocs/cms_Data/docs/pressData/PL/ec/101368.pdf.

38 Trotz Irland: Verheugen will die Türkei in der EU sehen, „Die Welt” z 8 VIII 2008. 
salach sądowych ${ }^{39}$. W RFN opinie potępiające rząd turecki spotkać można było na łamach bulwarowego dziennika „Bild-Zeitung”, który uważał, że Edogan „nie może wprowadzać swojego kraju do Europy i jednocześnie krok po kroku go islamizować [...] Europa nie jest chrześcijańskim klubem, ale jest wspólnotą wartości’" ${ }^{30}$.

Pewien postęp w 2008 r. odnotowano w rozwiązywaniu problemu cypryjskiego. W styczniu odwiedził Turcję po raz pierwszy od półwiecza grecki premier Konstantinos Karamanlis i wspólnie z premierem Erdoganem uzgodnili szukanie polubownych rozwiązań w najbardziej palących kwestiach bilateralnych. Zaowocowało to podjęciem rozmów przez przywódcę Turków cypryjskich Mehemeta Ali Talata i prezydenta republiki Cypryjskiej Dimitrisa Christofiasa, którzy 21 marca 2008 r. spotkali się w strefie buforowej ONZ w podzielonej Nikozji. W czasie spotkania liderzy uzgodnili wznowienie dwustronnych rozmów reunifikacyjnych oraz otwarcie ulicy Ledra w Nikozji, podzielonej na część północną i południową od lat sześćdziesiątych XX w. Na ponownym spotkaniu 1 lipca 2008 r. uzgodnili zasadę jednego obywatelstwa i jednej suwerenności, a na kolejnym - 3 września 2008 r. ogłosili rozpoczęcie właściwych i szczegółowych rozmów na temat zjednoczenia. Uzgodnione porozumienie miałoby być zatwierdzone w oddzielnych referendach dwóch społeczności. 30 września $2008 \mathrm{r}$. prezydent Christofias wystapił z propozycją demilitaryzacji Nikozji. Oba ministerstwa spraw zagranicznych - Turcji i Grecji ogłosiły wsparcie procesu zjednoczenia. W Ankarze istnieje świadomość, że zjednoczenie wyspy oznaczać będzie krok ku integracji z Unią, do której nie wejdzie bez zgody Cypru i Grecji1 ${ }^{41}$.

$* * *$

Nie ulega wątpliwości, że obecne obawy niemieckich i unijnych polityków, a także społeczeństwa Republiki Federalnej w sprawie przyjęcia Turcji, niewiele mają wspólnego z kosztami polityki rolnej, przestrzeganiem praw człowieka, problemami tureckich Kurdów czy sprawą Cypru ${ }^{42}$. W RFN konfrontowanej od blisko półwiecza na codzień z obecnością licznych Turków, (26\% z ogólnej liczby $6 \mathrm{mln} 750$ tys. cudzoziemców), gdzie procesy asymilacyjne przebijają się z olbrzymią trudnością, nadal silne jest przekonanie o trwającym zderzeniu cywilizacji i istnieniu - szczególnie po zamachach terrorystycznych fundamentalistów islamskich z początku XXI w. - przewagi elementów konfrontacji nad konstruktywnym współdziałaniem. Dynamizm świata islamskiego rodzi poczucie zagrożenia, perspektywę utraty wartości chrześcijańskich i zachwiania europejskiego kodu kulturowego. Badania opinii publicznej przeprowa-

39 Turecki sqd rozważy delegalizację rzqdu i prezydenta, „Gazeta Wyborcza” z 31 III 2008; Turcja: bez chust muzutmańskich na uniwersytecie, ibidem z 22 X 2008; J. Göttschlich, Erdogan attackiert Verfassungsrichter, „Die Tageszeitung” z 24 X 2008.

40 M. Backhaus, So nicht, Herr Erdogan, „Bild” z 8 II 2008. Por. R. Hermann, Debatte nach Erdogan-Besuch: Integriert euch, aber assimiliert euch nicht, „Frankfurter Allgemeine Zeitung” z 12 II 2008.

41 Z. Önis, Ş. Yilmaz, Greek-Turkish rapprochemen: rhetoric or reality?, „Political Science Quarterly” 2008, no. 1, s. 123-149; J. Pawlicki, Grecja i Turcja: zgoda w niezgodzie, „Gazeta Wyborcza” z 24 I 2008; Na Cyprze ruszyly rozmowy grecko-tureckie o zjednoczeniu wyspy, ibidem z 3 IX 2008.

42 A. Carkoglu, B. Rubin, Turkey and the European Union, London 2003, s. 175-178. 
dzone w końcu 2006 r. wskazywały, że już tylko 16\% Niemców wyobrażało sobie członkostwo Turcji w UE, a 93\% uzależniało je od postępu w przestrzeganiu praw człowieka i spełnianiu ekonomicznych kryteriów akcesji ${ }^{43}$. W niemieckich opiniach lista zastrzeżeń wobec Turcji i jej członkostwa w Unii jest długa. Widnieją na niej m.in.:

- obawa przed szybkim przyrostem naturalnym - obecnie Turcja liczy ponad $75 \mathrm{mln}$ mieszkańców, w 2015 r. prognozuje się, że ich liczba wzrośnie do $90 \mathrm{mln}$, przez co Turcja stałaby się najludniejszymn krajem UE;

- wspólnota wartości (UE jako klub chrześcijański) i odmienny kulturowo świat islamski z azjatycką mentalnością;

- tureckie „nie” dla uznania rzezi Ormian z lat 1915-1917 za ludobójstwo;

- łamanie praw człowieka (stosowanie tortur i ograniczanie wolności słowa) i prześladowanie mniejszości narodowych (represje wobec Kurdów);

- dyskryminacja kobiet (nierespektowanie równouprawnienia płci i tolerowanie tzw. „zabójstw na tle honoru”; już w 2004 r. eurodeputowani oskarżyli Ankarę o tolerowanie przemocy wobec kobiet, poligamii i przymusowych małżeństw);

- niestabilna i niedojrzała demokracja (zbyt duży wpływ wojskowych na sytuację polityczna);

- nierozwiązany konflikt cypryjski (niepewny status północnej części wyspy i nieprzychylne nastawienie greckich Cypryjczyków);

- zacofanie gospodarcze i relatywne ubóstwo społeczeństwa, a co za tym idzie, możliwość napływu do RFN taniej siły roboczej ${ }^{44}$.

Szczególny niepokój budzi olbrzymi przyrost naturalny w Turcji, gdyż rodzi on pytania o przyszły proces decyzyjny w Radzie Unii Europejskiej i Parlamencie Europejskim. RFN i Unia obawia się znacznego wzrostu kosztów utrzymania tak dużego i relatywnie biednego kraju, który stałby się największym odbiorcą unijnych funduszy strukturalnych i Funduszu Spójności. Odbyłoby się to zapewne kosztem zmniejszenia pomocy dla krajów Europy Środkowej i Wschodniej oraz zwiększenia obciążeń finansowych dla krajów bogatszych. „Stara” Unia obawia się przede wszystkim poszukujących pracy emigrantów z Turcji ${ }^{45}$.

43 Th. Jungholt, Deutsche wollen Türkei nicht in der Union, „Die Welt” z 20 XII 2006.

44 Szerzej zob. M. Hüttmann, Die Türkei ist Anders als Europa”; die öffentliche Debatte um einen EU-Beitritt der Türkei ind Deutschland, w: A. Giannakopoulos, K. Maras (Hrsg.), Die Türkei-Debatte ind Europa, Wiesbaden 2005; D. Oberndorfer, Die Furcht von der Türkei, w: S. Frech, Europa und die Türkei, Schwalbach 2006; C. Schőnig, Deutschland-und Deutschlandbild der Türken, w: ibidem; J. Cremer, Türkei und die europäische Identität, Bundeszentrale für Politische Bildung, http://www.bpb.de/themen/H4C1DD,0,Die_T\%FCrkei_und_die_europ\%E4ische_Identit\%E4t.html; U. Steinbach, Türkei und die EU. Probleme der geografischen, kulturellen und politischen Grenznziehung, Bundeszentrale für Politische Bildung, http://www.bpb.de/themen/2K6KOM"0,Probleme_der_geografischenkulturellen_und_politischen_Grenzziehung.html; W. Przewieslik, Auf dem Weg nach Europa?: Am Abschied vom nationalistischen Kemalismus und Islamismus misst sich die EU-Reife der Türkei; die Beitrittsdebatte muss vor allem als Wertedebatte geführt werden, „Die politische Meinung" 2006, nr 51, s. 63-68; J. Redmond, Turkey and the European Union: troubled European or European trouble?, „International Affairs”, no. 83 (March 2007) 2, s. 305-317; H. Schoen, Die Deutschen und die Türkeifrage: eine Analyse der Einstellungen zum Antrag der Türkei auf Mitgliedschaft in der Europäischen Union, „Politische Vierteljahresschrift” 2008, nr 1, s. 68-91.

45 S. von Oppeln, Die Debatte über den EU-Beitritt der Türkei im deutsch-französischen Vergleich, w: T. Baumann (Hg.), Die Türkei auf dem Weg in die Europäische Union, Berlin 2006, s. 11-30; 
Nie ulega wątpliwości, że na członkostwie w Unii najbardziej skorzysta Turcja. $Z$ dużym prawdopodobieństwem można założyć, że w wyniku akcesji nastąpi znaczne przyspieszenie tempa wzrostu PKB, poprawi się jakość działania instytucji publicznych, kraj ten uzyska dostęp do jednolitego rynku, a kilka lub kilkanaście lat później także do unijnego rynku pracy. Nie wiadomo jednak, czy Turcja otrzyma od razu znaczne wsparcie finansowe. Bruksela zastrzega, że kraj ten może być wyłączony na pewien czas z programów pomocowych.

W Republice Federalnej przewiduje się, że negocjacje akcesyjne będą trwały 10 i więcej lat. Obecnie można wysunąć pod adresem Turcji wiele zastrzeżeń, jednakże ogólne tendencje zarówno w dziedzinie utrwalania demokracji, jak i unowocześniania gospodarki uważać można za pozytywne. Dzięki naciskom Brukseli tureckie władze rezygnują z uciekania się do rozwiązań stojących w sprzeczności z fundamentalnymi zasadami państwa prawa. Perspektywa członkostwa jest bardzo silnym bodźcem do zintensyfikowania zmian w zakresie reform gospodarczych, przestrzegania standardów demokracji oraz praw człowieka ${ }^{46}$. Rząd w Ankarze wprowadził reformy wzmacniające zasady demokracji: rozszerzono wolność prasy, zniesiono zakaz używania języków lokalnych w szkołach i mediach, przekształcono Narodową Radę Bezpieczeństwa w organ doradczy z przewagą pracowników cywilnych. W widoczny sposób poprawiła się również sytuacja mniejszości kurdyjskiej, która stała się zwolennikiem przystapienia Turcji do $\mathrm{UE}^{47}$.

Niemieccy orędownicy członkostwa Turcji z SPD, Partii Zielonych czy Lewicy wskazują na poprawne stosunki tego państwa z Iranem, dobre z Syrią i Irakiem, wyjątkowe w porównaniu z innymi państwami bliskowschodnimi relacje z Izraelem, co sprawia, że Ankara może wnieść do Unii atrakcyjny posag jako stabilny partner w niebezpiecznym regionie Bliskiego Wschodu. Odrzucenie kandydatury Turcji mogłoby doprowadzić w tym kraju do wzmocnienia eurosceptyków i rozpadu konsensusu prounijnego, a w efekcie do wyhamowania reform. Unia u swych granic miałaby kraj „obrażony”, niestabilny politycznie i gospodarczo. Zmniejszyłaby się również możliwość prowadzenia przez UE efektywnej polityki wobec Bliskiego Wschodu, Azji Centralnej i Kaukazu ${ }^{48}$.

Obecnie coraz częściej podkreśla się, że przyjęcie Turcji byłoby wyraźnym dowodem, że UE nie jest zamkniętą twierdzą. Świadczyłoby to także o jej tolerancji i otwartości oraz uznaniu islamu za religię do pogodzenia z zachodnią liberalną demokracją. Byłoby to również zaprzeczenie tezy, że świat skazany jest na „zderzenie cywilizacji”, a Europa odegrałaby niezwykle ważną rolę w procesie kształtowania wzajemnych relacji między Zachodem a światem islamu.

Ł. Bartkowiak, Unia Europejska wobec Bałkanów Zachodnich i Turcji, „Przegląd Zachodni” 2006, nr 4, s. 119-146.

${ }^{46}$ Por. A. Balcer, R. Sadowski, W. Paczyński, Turkey after the start of negotiations wit the European Union - foreign relations and domestic situation, „Raport OSW”, Part. I, Warsaw, June 2007.

47 R. Dymek, M. Święcicki, Więcej niż Turcja, „Gazeta Wyborcza” z 7 X 2004.

${ }^{48}$ K. Kaiser, Strategischer Partner Türkei: jenseits der Erweiterungsdebatte: warum wir Ankara brauchen, „Internationale Politik” 2007, nr 5, s. 100-107; A. Balcer, Nie taka Turcja straszna, „Gazeta Wyborcza" z 22 XII 2004. 